Jurnal Perikanan (2021) Volume 11. No. $1: 1-12$

DOI : https://doi.org/10.29303/jp.v11i1.224

\title{
PERCEPATAN PERTUMBUHAN BENIH KERANG MUTIARA (Pinctada maxima) MENGGUNAKAN METODA PERENDAMAN DALAM BAK PAKAN ALAMI
}

\author{
ACCELERATED GROWTH OF PEARL OYSTER SEEDS (PINCTADA \\ MAXIMA) USING IMMERSION METHOD IN NATURAL FEED CONTAINER \\ Alis Mukhlis*, Nadirah Karimatul Ilmi, Sanca Rahmatullah, Anita Prihatini Ilyas dan \\ Awan Dermawan
}

Program Vokasi Unram, Program di Luar Domisili (PDD) Kabupaten Bima

*Alamat korespondensi : alismukhlis@unram.ac.id

\begin{abstract}
Abstrak
Kerang mutiara (Pinctada maxima) merupakan salah satu sumber daya laut yang memiliki nilai ekonomi tinggi namun produksinya membutuhkan waktu yang lama, sehingga membutuhkan waktu yang lama untuk dipasarkan. Ketidak seimbangan antara kebutuhan pakan dengan ketersediaan pakan alami di perairan diduga menjadi salah satu faktor lambatnya pertumbuhan benih kerang mutiara. Permasalahan ini dapat ditanggulangi dengan melakukan perendaman dalam bak pakan alami secara periodik sehingga kebutuhan pakan benih kerang mutiara dapat terpenuhi. Tujuan dari penelitian ini adalah untuk mengetahui pengaruh periode perendaman benih dalam bak pakan alami terhadap pertumbuhan benih kerang mutiara. Penelitian ini dilaksanakan pada Juni - September 2019 di Teluk Siung, Desa Batu Putih, Kecamatan Sekotong Barat, Kabupaten Lombok Barat, Nusa Tenggara Barat. Rancangan yang digunakan adalah rancangan acak lengkap teridiri atas lima perlakuakn yaitu A, tanpa perendaman (sebagi kontrol); B, perendaman dengan interval 1 minggu; $C$, perendaman dengan interval 2 minggu; $D$, perendaman dengan interval 3 minggu; dan $\mathrm{E}$, perendaman dengan interval 4 minggu. Hasil penelitian menunjukkan bahwa perendaman dalam bak pakan alami memberi pengaruh yang signifikan pada pertumbuhan cangkang (dorso-ventral) benih kerang mutiara Pinctada maxima $(p<0,05)$. Pertumbuhan tertinggi dicapai pada perendaman dengan interval waktu tiap 2 minggu denga nilai pertumbuhan mutlak sebesar $10,99 \mathrm{~mm}$, pertumbuhan spesifik sebesar $219,8 \%$ dari ukuran awal, dan laju pertumbuhan spesifik sebesar 1,30\% per hari. Metode ini perlu diuji pada benih yang berukuran lebih besar dari yang digunakan dalam penelitian ini untuk melihat konsistensi penerapan metoda perendaman dalam budidaya benih kerang mutiara.
\end{abstract}

Kata kunci : Pertumbuhan, Pinctada maxima, perendaman, pakan alami

\begin{abstract}
Pearl oyster (Pinctada maxima) is one of the marine resources that has high economic value but its production takes a long time, so it takes a long time to be marketed. The imbalance between feed requirements and the availability of natural food in the waters is thought to be one of the factors for the slow growth of pearl oyster seeds. This problem can be overcome by immersing it in natural feed tanks periodically so that the need for pearl
\end{abstract}


Jurnal Perikanan (2021) Volume 11. No. $1: 1-12$

DOI : https://doi.org/10.29303/jp.v11i1.224

oyster seed feed can be met. The purpose of this study was to determine the effect of the immersion period of seeds in natural feed tanks on the growth of pearl oyster seeds. This research was conducted in June - September 2019 in Teluk Siung, Batu Putih Village, West Sekotong District, West Lombok Regency, West Nusa Tenggara. The design used was a completely randomized design consisting of five treatments, namely A, without immersion (as a control); B, immersion at intervals of 1 week; C, soaking at intervals of 2 weeks; D, immersion at intervals of 3 weeks; and $\mathrm{E}$, immersion at 4-week intervals. The results showed that immersion in natural feed tanks had a significant effect on the growth of the shell (dorsoventral) of Pinctada maxima pearl shells $(\mathrm{p}<0.05)$. The highest growth was achieved in immersion with time intervals every 2 weeks with an absolute growth value of $10.99 \mathrm{~mm}$, a specific growth of $219.8 \%$ of the initial size, and a specific growth rate of $1.30 \%$ per day. This method needs to be tested on seeds that are larger than those used in this study to see the consistency of the application of the immersion method in the cultivation of pearl oyster seeds.

Key Words : growth, Pinctada maxima, immersion, natural food

\section{PENDAHULUAN}

Tiram mutiara merupakan salah satu biota laut yang hampir semua bagian dari tubuhnya mempunyai nilai jual, baik mutiara, cangkang, daging dan organisme tiram itu sendiri benih maupun induk). Jenis-jenis tiram mutiara yang ada di Indonesia adalah Pinctada maxima, P. margaritifera, P. chimnitzii, P. fucata dan Pteria penguin. Dari kelima spesies tersebut yang dikenal sebagai penghasil mutiara terpenting yaitu $\mathrm{P}$. maxima, $\mathrm{P}$. margaritifera dan Pteria penguin.

Perairan Indonesia sendiri memiliki potensi Tiram mutiara (Pinctada maxima) yang begitu besar di wilayah Indonesia bagian timur seperti Irian Jaya, Sulawesi dan gugusan laut Arafuru. Di beberapa daerah tersebut, usaha penyelaman tiram mutiara merupakan mata pencaharian bagi penduduk setempat. Gairah para penyelam semakin kuat setelah berdirinya beberapa perusahaan mutiara, karena jalur pemasaran tiram mutiara hasil menyelam cukup baik mengingat perusahaan tersebut masih membeli tiram dari para penyelam (Tarwiyah, 2001).

Kerang mutiara (Pinctada maxima) merupakan salah satu sumber daya laut yang memiliki nilai ekonomi tinggi namun produksinya membutuhkan waktu yang lama, sehingga membutuhkan waktu yang lama untuk dipasarkan. Ketidakseimbangan antara kebutuhan pakan dengan ketersediaan pakan alami di perairan diduga menjadi salah satu faktor lambatnya pertumbuhan benih kerang mutiara. Permasalahan ini dapat ditanggulangi dengan melakukan perendaman dalam bak pakan alami secara periodik sehingga kebutuhan pakan benih kerangmutiara dapat terpenuhi. Tujuan dari penelitian ini adalah untuk mengetahui pengaruh periode perendaman benih dalam bak pakan alami terhadap pertumbuhan benih kerang mutiara.

Materi dan Metode Penelitian ini dilaksanakan pada Juni - September 2019 di Teluk Siung, Desa Batu Putih, Kecamatan Sekotong Barat, Kabupaten Lombok Barat, Nusa Tenggara Barat. Rancangan yang digunakan adalah rancangan acak lengkap. Perlakuan yang diuji dalam penelitian ini teridiri atas lima perlakuakn yaitu A, tanpa perendaman (sebagi kontrol); B, perendaman dengan interval 1 minggu; $\mathrm{C}$, perendaman dengan interval 2 minggu; $\mathrm{D}$, perendaman dengan interval 3 minggu; dan $\mathrm{E}$, 
Jurnal Perikanan (2021) Volume 11. No. $1: 1-12$

DOI : https://doi.org/10.29303/jp.v11i1.224

perendaman dengan interval 4 minggu.

pembiayaannya dianggarkan dalam proposal ini.

Penelitian dilakukan dengan tahapan sebagai berikut :

1) Koleksi/pengadaan bibit pakan alami dan propagasi stok pakan (diatom)

Benih pakan alami (diatom) dikoleksi/didatangkan dari Stasiun Budidaya Laut Dinas Perikanan dan Kalutan Provinsi NTB. Bibit yang diperoleh kemudian dikembangbiakan pada lab. mini hingga mencapai kepadatan serta volume kultur yang dibutuhkan untuk penelitian (Gambar 4). Kultur pakan alami dibebankan

2) Persiapan hewan uji (kerang mutiara stadia spat)

Spat kolektor didatangkan dari produsen spat kerang mutiara yang telah memiliki reputasi baik sebagai produsen spat yang berkualitas seperti dari kabupaten Karangasem dan kabupaten Buleleng Provinsi Bali. Sebanyak sekitar 25 kolektor spat yang dibutuhkan dalam enelitian ini. Masing-masing perlakuan menggunakan 6 unti spat kolektor. kepada satu orang teknisi yang
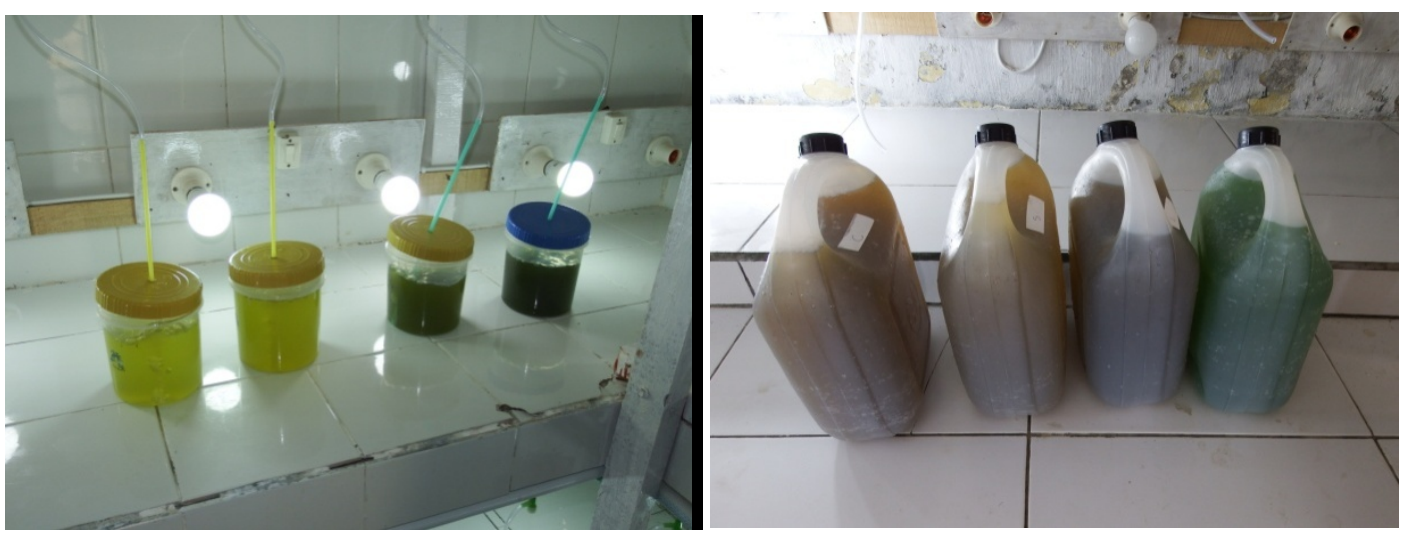

Gambar 4. Bibit mikroalga (Digenea simplex, Tetraselmis spp., Chaetoceros amami, Chaetoceros calcitran) yang digunakan dalam penelitian.

3) Penebaran hewan uji

Penebaran hewan uji dilakukan pada pagi atau sore hari. Penebaran

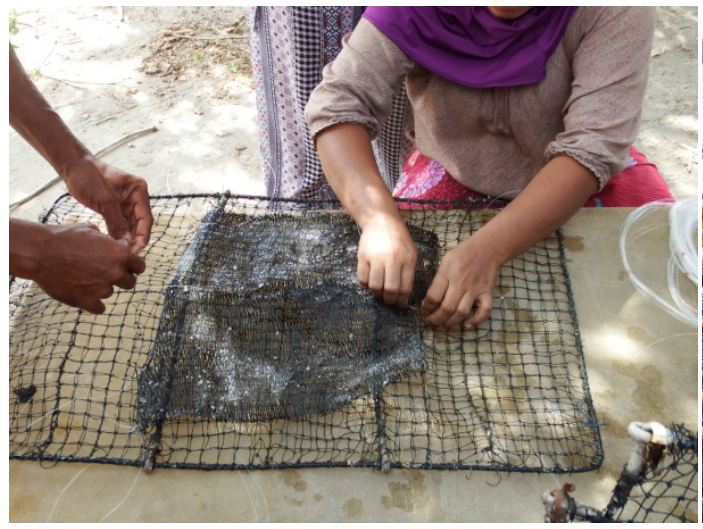

dilakukan secara-hati-hati untuk menghindari munculnya setress pada benih kerang mutiara.

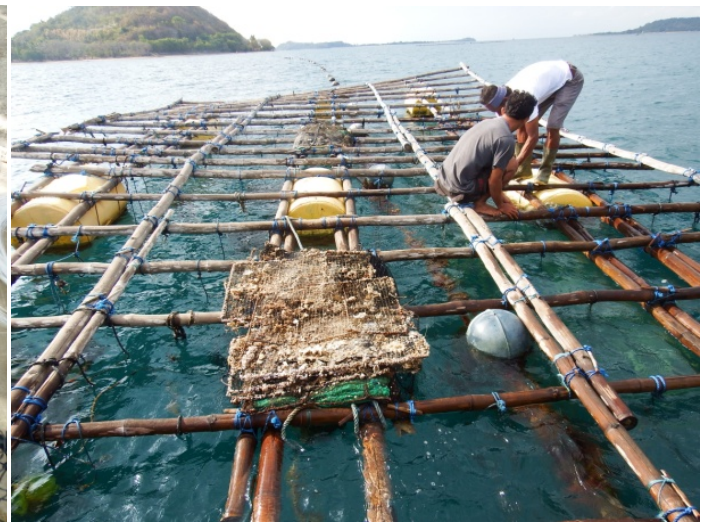

Gambar 5. Persiapan spat pada kolektor dan penebaran di karamba apung 
Jurnal Perikanan (2021) Volume 11. No. $1: 1-12$

DOI : https://doi.org/10.29303/jp.v11i1.224

4) Koleksi data parameter fisika, kimia dan biologi perairan

Parameter-parameter yang diukur dan menggambarkan kondisi kualitas perairan yaitu kecerahan air, arus air, suhu, salinitas, derajat keasaman $(\mathrm{pH})$, dan kandungan oksigen terlarut (Gambar 6). Parameter ini diukur 2 minggu sekali selama periode penelitian. Data-data dari parameter

ini digunakan sebagai data pembanding untuk mendiskripsikan kondisi lingkungan penelitian. Selain parameter ini, kelimpahan plankton terutama kelompok diatom serta jenisjenisnya juga dikoleksi dan dianalisis sebagai perlakuan kontrol pada perlakuan pemberian pakan alami menggunakan metode perendaman.

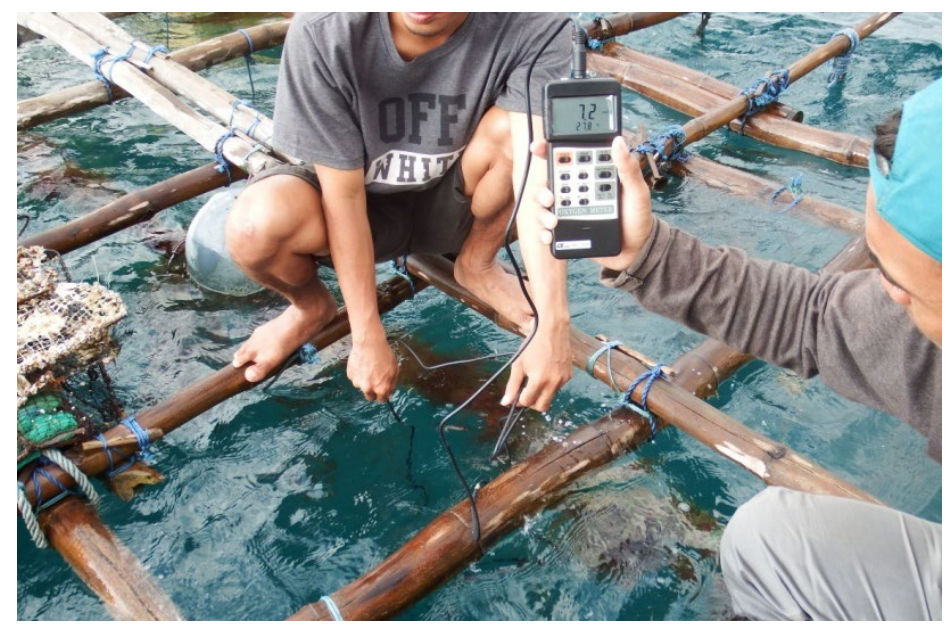

Gambar 6. Pengukuran kualitas perairan di lingkungan karamba apung

5) Perendaman dalam larutan pakan dan Pemeliharaan benih kerang mutiara Pemeliharaan dilakukan selama 3 bulan. Selama pemeliharaan dilakukan perendaman benih dalam bak fiber dengan interval waktu sesuai dengan perlakuan (Gambar 7). Pembersihan kerang mutiara dilakukan setiap 2 minggu pada saat pemberian pakan.

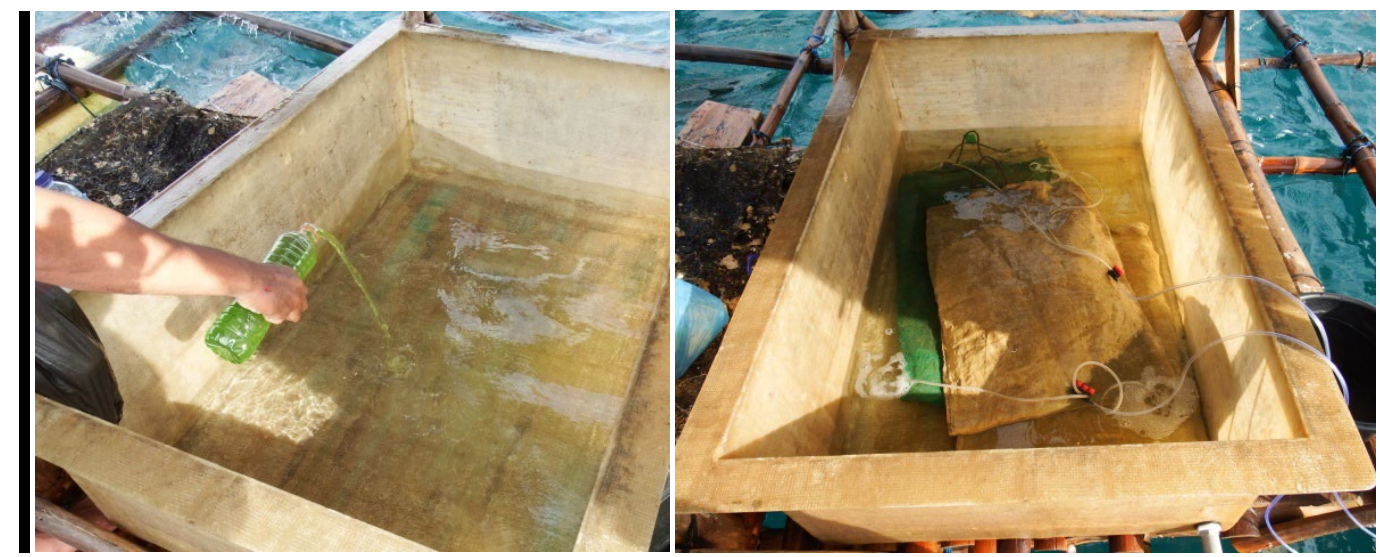

Gambar 7. Perendaman benih kerang mutiara dalam bak pakan alami

6) Pengukuran panjang tubuh
Panjang tubuh hewan uji diukur 
Jurnal Perikanan (2021) Volume 11. No. $1: 1-12$

DOI : https://doi.org/10.29303/jp.v11i1.224

berdasarkan panjang dorso-ventral

menggunakan jangka sorong digital (Gambar 8). Pengukuran dilakukan setiap satu bulan sejak penebaran.

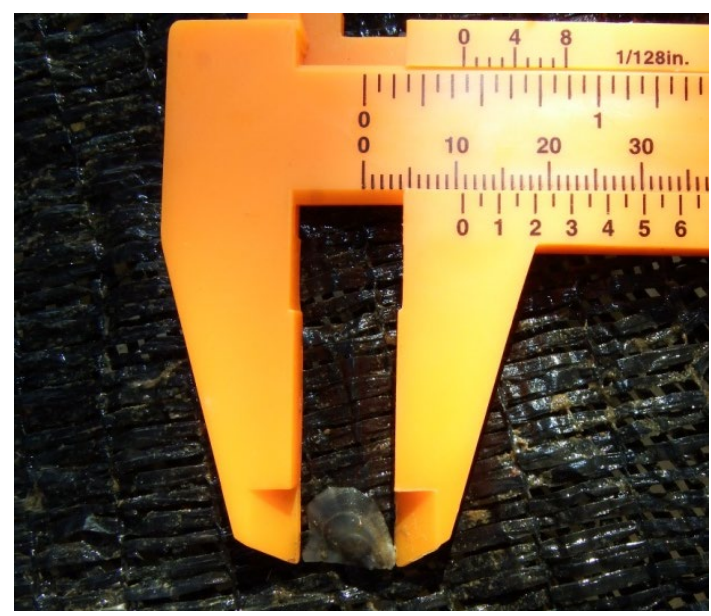

Gambar 8. Pengukuran panjang cangkang benih kerang mutiara

7) Parameter uji

Parameter uji yang diamati dalam penelitian ini meliputi : pertumbuhan mutlak, petumbuhan relatif, laju pertumbuhan spesifik harian, tingkat kelangsungan hidup, dan tingkat serapan pakan. Penentuan parameter uji ditentukan dengan menggunakan rumus sebagai beriukut :

a. Pertubuhan Mutlak

$\beta=L_{t}-L_{0}$

Keterangan :

$\beta=$ Pertumbuhan mutlak (mm)

$L_{0}=$ Panjang kerang pada awal percobaan $(\mathrm{mm})$

$L_{t}=$ Panjang kerang pada waktu $t$ (mm)

b. Pertumbuhan Relatif

$\alpha=\left[\left(L_{t}-L_{0}\right) / L_{0}\right] \times 100 \%$

Keterangan :

$\alpha=$ Pertumbuhan relatif ( $\%)$

$L_{0}=$ Panjang kerang pada awal percobaan $(\mathrm{mm})$

$L_{t}=$ Panjang kerang pada waktu $t$ (mm)

c. Laju Pertumbuhan Spesifik Harian
$\mu=\left[\left(L_{t} / L_{0}\right)^{\wedge}(1 / t)-1\right] \times 100 \%$

Keterangan :

$\mu=$ LajuPertumbuhan Spesifik Harian (\% per hari)

$L_{0}=$ Panjang kerang pada awal percobaan $(\mathrm{mm})$

$L_{t}=$ Panjang kerang pada waktu $t$ (mm)

$t$ = Lama percobaan (hari)

\section{HASIL DAN PEMBAHASAN \\ Panjang Dorso-Ventral}

Hasil Pengukuran Panjang Dorso-

Ventral yang dilakukan pada akhir percobaan memperlihatkan bahwa panjang benih kerang mutiara yang diberi perlakuan perendaman dalam bak pakan alami secara periodik dengan jarak perendaman 2 minggu menunjukkan panjang rata-rata tertinggi dengan nilai rerata \pm S.D sebesar $16,0 \pm 0,7 \mathrm{~mm}$. Nilai tertinggi berikutnya diperoleh pada jarak perendaman 3, 4, kontrol (tanpa perendaman), dan 1 minggu dengan nilai rerata \pm S.D masing-masing secara berurutan sebesar $14,6 \pm 1,0 \mathrm{~mm} ; 14,0 \pm$ $1,3 \mathrm{~mm} ; 13,7 \pm 0,8 \mathrm{~mm}$; dan 13,4 $\pm 0,7$ mm (Tabel 1 dan Gambar 9). 
Jurnal Perikanan (2021) Volume 11. No. $1: 1-12$

DOI : https://doi.org/10.29303/jp.v11i1.224

Tabel 1. Data Hasil Pengukuran Panjang Dorso-Ventral Akhir Percobaan

\begin{tabular}{cccccccc}
\hline $\begin{array}{c}\text { Interval } \\
\text { Perendaman } \\
\text { (minggu) }\end{array}$ & $\mathbf{1}$ & $\mathbf{2}$ & $\mathbf{3}$ & $\mathbf{4}$ & $\mathbf{5}$ & RERATA & SD \\
\cline { 2 - 6 } & 14,0 & 13,6 & 12,4 & 13,8 & 14,8 & 13,7 & 0,8 \\
\hline (kontrol) & 13,7 & 12,9 & 12,9 & 14,5 & 13,0 & 13,4 & 0,7 \\
1 & 15,2 & 16,7 & 15,3 & 16,3 & 16,5 & 16,0 & 0,7 \\
2 & 15,1 & 14,1 & 15,9 & 13,4 & 14,2 & 14,6 & 1,0 \\
3 & 15,4 & 13,5 & 15,4 & 13,3 & 12,6 & 14,0 & 1,3 \\
\hline
\end{tabular}

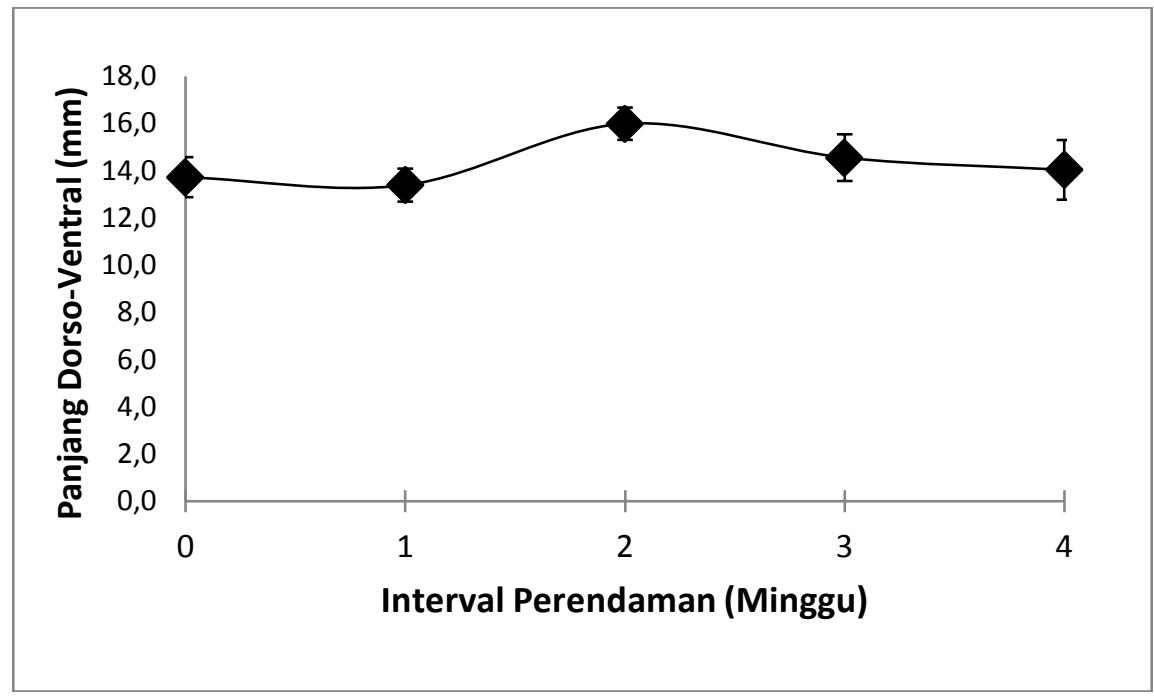

Gambar 9. Grafik ukuran Dorso-Ventral benih kerang mutiara yang direndam dalam bak pakan alami dengan interval perendaman 0 (kontrol), 1, 2, 3, dan 4 minggu.

\section{Analisis Keragaman Data \\ Pertumbuhan}

Parameter pertumbuhan yang diamati dalam penelitian ini meliputi pertumbuhan mutlak, pertumbuhan relatif, dan laju pertumbuhan spesifik harian.

\section{1) Pertumbuhan Mutlak}

Hasil analisis pertumbuhan mutlak benih yang dipelihara selama 90 hari memperlihatkan bahwa pertambahan ukuran tertinggi dicapai pada perlakuan dengan interval perendaman selama 2 minggu dengan pertambahan ukuran ratarata sebesar 10,99 $\mathrm{mm}$ (Tabel 2).

Tabel 2. Data Pertumbuhan Mutlak (mm) 
Jurnal Perikanan (2021) Volume 11. No. $1: 1-12$

DOI : https://doi.org/10.29303/jp.v11i1.224

\begin{tabular}{rrrrrr}
\hline Ulangan & 0 (kontrol) & 1 & 2 & 3 & 4 \\
\hline 1 & 9,0 & 8,7 & 10,2 & 10,1 & 10,4 \\
2 & 8,6 & 7,9 & 11,7 & 9,1 & 8,5 \\
3 & 7,4 & 7,9 & 10,3 & 10,9 & 10,4 \\
4 & 8,8 & 9,5 & 11,3 & 8,4 & 8,3 \\
5 & 9,8 & 8,0 & 11,5 & 9,2 & 7,6 \\
\hline Retara & $\mathbf{8 , 7 2}$ & $\mathbf{8 , 3 9}$ & $\mathbf{1 0 , 9 9}$ & $\mathbf{9 , 5 5}$ & $\mathbf{9 , 0 3}$ \\
\hline $\boldsymbol{S D}$ & $\mathbf{0 , 8}$ & $\mathbf{0 , 7}$ & $\mathbf{0 , 7}$ & $\mathbf{1 , 0}$ & $\mathbf{1 , 3}$ \\
\hline
\end{tabular}

Hasil analisis sidik ragam menunjukkan bahwa interval perendaman benih dalam bak pakan alami memberi pengaruh yang signifikan pada pertumbuhan mutlak panjang DorsoVentral cangkang benih kerang mutiara $P$. maxima $(p<0,05)$ (Tabel 3). Hasil analisis uji lanjut menggunakan uji Beda Nayata Terkecil menunjukkan bahwa pertambahan panjang Dorso-Ventral benih yang diberi perlakuan perendaman dengan interval 2 minggu nilainya berbeda nyata dengan empat perlakuan lainnya baik terhadap kontrol (tanpa perlakuan perendaman) maupun terhadap perendaman dengan interval 1, 3, dan 4 minggu (Tabel 4 dan Gambar 10).

Tabel 3. Analisis keragaman pertumbuhan mutlak $(\mathrm{mm})$ benih kerang mutiara $P$. maxima yang direndam dalam bak pakan alami dengan interval 0 (kontrol), 1 , 2, 3, dan 4 minggu.

\begin{tabular}{lrrrrrr}
\hline $\begin{array}{l}\text { Sumber } \\
\text { Keragaman }\end{array}$ & $d b$ & $J K$ & $K T$ & F hit & F tab 5\% & P-value \\
\hline Perlakuan & 4 & 20,70 & 5,18 & 6,1 & 2,87 & 0,002 \\
Galat & 20 & 16,98 & 0,85 & & & \\
Total & 24 & 37,67 & & & & \\
\hline
\end{tabular}

Tabel 4. Hasil Uji lanjut Beda Nyata Terkecil (BNT)

$\begin{array}{llll}\text { No. } & \text { Perlakuan } & \text { Rerata } & \text { Notasi Signifikan } \\ --1 & 2 & -------- & ------- \\ 2 & 3 & 10,99 & \mathrm{~b} \\ 3 & 4 & 9,55 & \mathrm{a} \\ 4 & 0 \text { (kontrol) } & 9,03 & \mathrm{a} \\ 5 & 1 & 8,72 & \mathrm{a} \\ \end{array}$

Nilai BNT $0,05=1,227$ 
Jurnal Perikanan (2021) Volume 11. No. $1: 1-12$

DOI : https://doi.org/10.29303/jp.v11i1.224

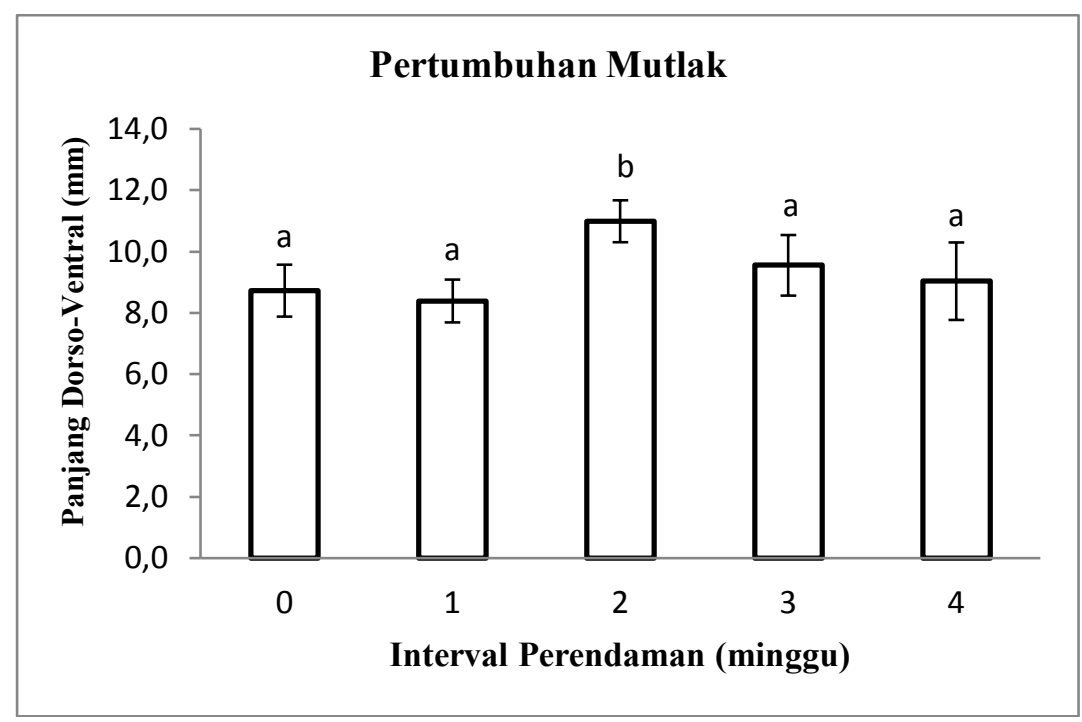

Gambar 10. Grafik pertumbuhan mutlak Panjang Cangkang Benih Kerang Mutiara (ukuran Dorso-Ventral)

\section{2) Pertumbuhan Relatif}

Hasil analisis pertumbuhan relatif panjang cangkang Dorso-ventral benih kerang mutiara $P$. maxima yang dipelihara selama 90 hari memperlihatkan bahwa pertambahan ukuran tertinggi dicapai pada perlakuan dengan interval perendaman selama 2 minggu dengan pertambahan ukuran rata-rata sebesar $219,8 \%$ dari ukuran cangkang saat awal pemeliharaan (Tabel 5).

Hasil analisis sidik ragam menunjukkan bahwa interval perendaman benih dalam bak pakan alami memberi pengaruh yang signifikan pada pertumbuhan relatif panjang DorsoVentral cangkang benih kerang mutiara $P$. maxima $(p<0,05)($ Tabel 8). Hasil analisis uji lanjut menggunakan uji Beda Nayata Terkecil menunjukkan bahwa pertambahan panjang Dorso-Ventral benih yang diberi perlakuan perendaman dengan interval 2 minggu nilainya berbeda nyata dengan empat perlakuan lainnya baik terhadap kontrol (tanpa perlakuan perendaman) maupun terhadap perendaman dengan interval 1,3 , dan 4 minggu (Tabel 6 dan Gambar 11).

Tabel 5. Data Pertumbuhan Relatif (\%) benih kerang mutiara P. maxima yang direndam dalam bak pakan alami dengan interval 0 (kontrol), 1, 2, 3, dan 4 minggu.

\begin{tabular}{rrrrrr}
\hline & \multicolumn{3}{l}{ Interveal Perendaman (minggu) } & & \\
\cline { 2 - 6 } Ulangan & 0 (kontrol) & 1 & 2 & 3 & 4 \\
\hline 1 & 180,0 & 174,7 & 204,8 & 202,3 & 207,6 \\
2 & 171,8 & 157,0 & 233,5 & 182,6 & 170,0 \\
3 & 148,7 & 157,9 & 205,5 & 218,9 & 207,3 \\
4 & 176,5 & 189,2 & 225,0 & 168,0 & 165,4 \\
5 & 195,5 & 160,0 & 230,0 & 183,3 & 153,0 \\
\hline Retara & $\mathbf{1 7 4 , 5}$ & $\mathbf{1 6 7 , 7}$ & $\mathbf{2 1 9 , 8}$ & $\mathbf{1 9 1 , 0}$ & $\mathbf{1 8 0 , 7}$ \\
\hline SD & $\mathbf{1 6 , 9}$ & $\mathbf{1 4 , 0}$ & $\mathbf{1 3 , 7}$ & $\mathbf{1 9 , 8}$ & $\mathbf{2 5 , 3}$ \\
\hline
\end{tabular}


Jurnal Perikanan (2021) Volume 11. No. $1: 1-12$

DOI : https://doi.org/10.29303/jp.v11i1.224

Tabel 6. Analisis keragaman pertumbuhan mutlak (\%) benih kerang mutiara P. maxima yang direndam dalam bak pakan alami dengan interval 0 (kontrol), 1, 2, 3, dan 4 minggu.

\begin{tabular}{lrrrrrr}
\hline Sumber Keragaman & $d b$ & $J K$ & $K T$ & $F$ hit & F tab 5\% & P-value \\
\hline Perlakuan & 4 & 8281,175 & 2070 & 6,1 & 2,87 & 0,002 \\
Galat & 20 & 6793,382 & 340 & & & \\
Total & 24 & 15074,56 & & & & \\
\hline
\end{tabular}

Tabel 7. Hasil Uji lanjut Beda Nyata Terkecil (BNT)

$\begin{array}{clll}\text { No. } & \text { Perlakuan } & \text { Rerata } & \text { Notasi Signifikan } \\ ---- & ----------- & --------- & --------- \\ 1 & 2 & 219,8 & \text { b } \\ 2 & 3 & 191,0 & \mathrm{a} \\ 3 & 4 & 180,7 & \mathrm{a} \\ 4 & 0 \text { (kontrol) } & 174,5 & \mathrm{a} \\ 5 & 1 & 167,8 & \mathrm{a}\end{array}$

Nilai BNT $0,05=\mathbf{2 4 . 3 0 7 4 5 1 9 9 3 6}$

3) Laju Pertumbuhan Spesifik Harian

Hasil analisis laju pertumbuhan spesies (LPS) harian panjang cangkang Dorso-ventral (\% per hari) benih kerang mutiara $P$. maxima yang dipelihara selama 90 hari memperlihatkan bahwa LPS harian tertinggi dicapai pada perlakuan dengan interval perendaman selama 2 minggu dengan nilai rata-rata sebesar 1,30 $\%$ per hari (Tabel 8).

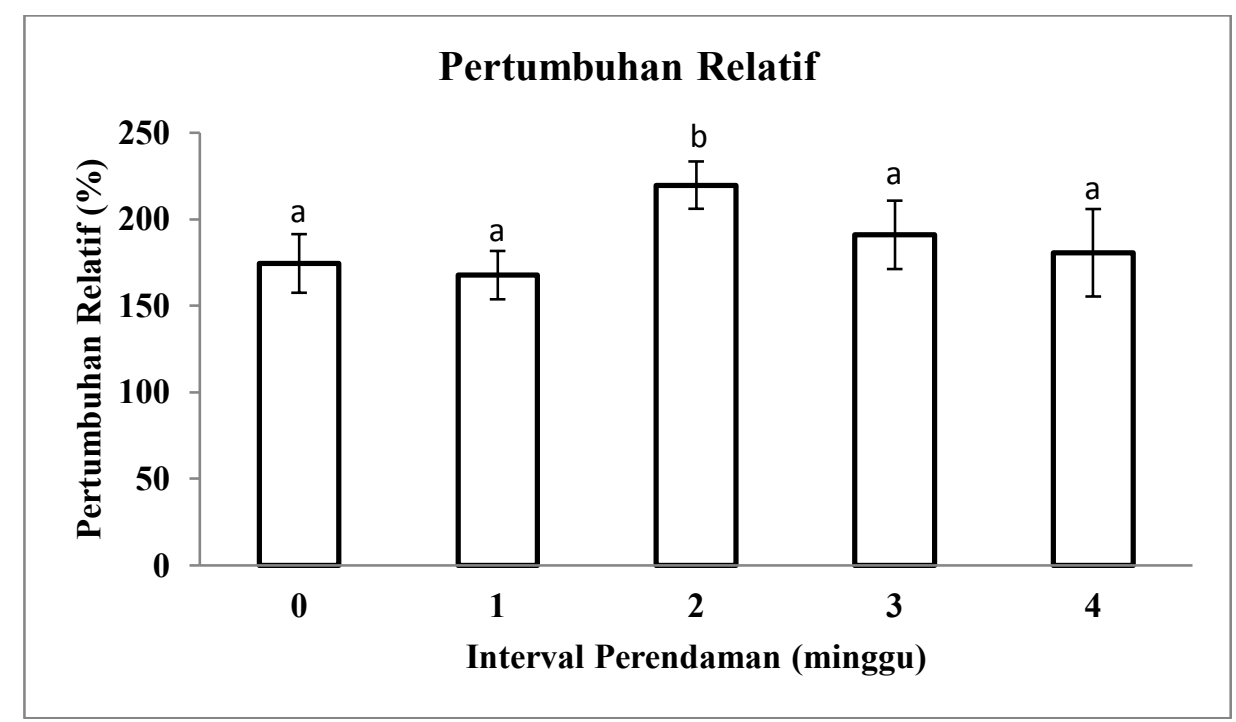

Gambar 11. Grafik pertumbuhan raltif Panjang Cangkang Benih Kerang Mutiara (ukuran Dorso-Ventral) 
Jurnal Perikanan (2021) Volume 11. No. $1: 1-12$

DOI : https://doi.org/10.29303/jp.v11i1.224

Tabel 8. Data Laju Pertumbuhan Spesifik Harian (\% per hari) panjang Dorso-Ventral cangkang benih kerang mutiara $P$. maxima yang direndam dalam bak pakan alami dengan interval 0 (kontrol), 1, 2, 3, dan 4 minggu.

\begin{tabular}{rrrrrr}
\hline \multirow{2}{*}{ Ulangan } & \multicolumn{2}{l}{ Interval Perendaman (minggu) } & & & \\
\cline { 2 - 6 } & 0 (kontrol) & 1 & 2 & 3 & 4 \\
\hline 1 & 1,15 & 1,13 & 1,25 & 1,24 & 1,26 \\
2 & 1,12 & 1,05 & 1,35 & 1,16 & 1,11 \\
3 & 1,02 & 1,06 & 1,25 & 1,30 & 1,26 \\
4 & 1,14 & 1,19 & 1,32 & 1,10 & 1,09 \\
5 & 1,21 & 1,07 & 1,34 & 1,16 & 1,04 \\
\hline Retara & $\mathbf{1 , 1 3}$ & $\mathbf{1 , 1 0}$ & $\mathbf{1 , 3 0}$ & $\mathbf{1 , 1 9}$ & $\mathbf{1 , 1 5}$ \\
\hline $\mathbf{S D}$ & $\mathbf{0 , 0 7}$ & $\mathbf{0 , 0 6}$ & $\mathbf{0 , 0 5}$ & $\mathbf{0 , 0 8}$ & $\mathbf{0 , 1 0}$ \\
\hline
\end{tabular}

Hasil analisis sidik ragam menunjukkan bahwa interval perendaman benih dalam bak pakan alami memberi pengaruh yang signifikan pada laju pertumbuhan spesifik harian panjang Dorso-Ventral cangkang benih kerang mutiara P. maxima $(p<0,05)$ (Tabel 9). Hasil analisis uji lanjut menggunakan uji Beda Nayata Terkecil menunjukkan bahwa laju pertumbuhan spesifik harian panjang Dorso-Ventral benih yang diberi perlakuan perendaman dengan interval 2 minggu nilainya berbeda nyata dengan empat perlakuan lainnya baik terhadap kontrol (tanpa perlakuan perendaman) maupun terhadap perendaman dengan interval 1, 3, dan 4 minggu (Tabel 10 dan Gambar 12).

Tabel 9. Analisis keragaman pertumbuhan mutlak (\%) benih kerang mutiara P. maxima yang direndam dalam bak pakan alami dengan interval 0 (kontrol), 1, 2, 3, dan 4 minggu.

\begin{tabular}{lrrrrrr}
\hline $\begin{array}{l}\text { Sumber } \\
\text { Keragaman }\end{array}$ & $d b$ & $J K$ & $K T$ & F hit & F tab 5\% & P-value \\
\hline Perlakuan & 4 & 0,122 & 0,03 & 5,76 & 2,87 & 0,003 \\
Galat & 20 & 0,106 & 0,01 & & & \\
\hline Total & 24 & 0,228 & & & & \\
\hline
\end{tabular}

Tabel 10. Hasil Uji lanjut Beda Nyata Terkecil (BNT)

$\begin{array}{llll}\text { No. } & \text { Perlakuan } & \text { Rerata } & \text { Notasi Signifikan } \\ ---- & ------ \\ 1 & 2 & 1,30 & \text { b } \\ 2 & 3 & 1,19 & \mathrm{a} \\ 3 & 4 & 1,15 & \mathrm{a} \\ 4 & 0 \text { (kontrol) } & 1,13 & \mathrm{a} \\ 5 & 1 & 1,10 & \mathrm{a}\end{array}$

Nilai BNT $0,05=\mathbf{0 . 0 9 6}$ 


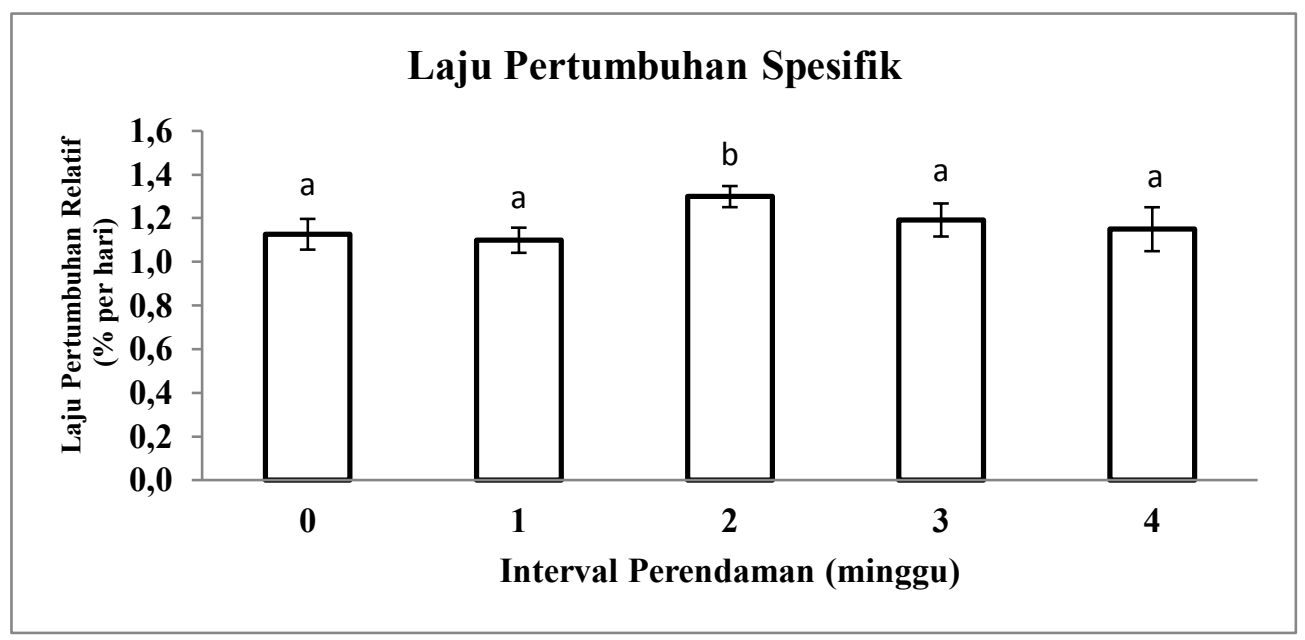

Gambar 12. Grafik laju pertumbuhan spesifik harian Panjang Cangkang Benih Kerang Mutiara (ukuran Dorso-Ventral)

\section{KESIMPULAN DAN SARAN}

\section{Kesimpulan :}

Kesimpulan yang dapat diambil dari penelitian ini adalah : 1) Periode perendaman dalam bak pakan alami memberi pengaruh yang signifikan pada pertumbuhan cangkang (dorso-ventral) benih kerang mutiara Pinctada maxima baik dari parameter pertumbuhan mutlak, pertumbuhan relatif, maupun laju pertumbuhan spesifik; 2) Pertumbuhan tertinggi dicapai pada perendaman dengan interval waktu tiap 2 minggu dengan nilai pertumbuhan mutlak sebesar $10,99 \mathrm{~mm}$, pertumbuhan relatif sebesar $219,8 \%$ dari ukuran awal, laju pertumbuhan spesifik sebesar 1,30 \% per hari; 3) Perlakuan perendaman dengan interval 2 minggu memberikan respon yang berbeda signifikan dibandingkan dengan interval 1, 3, 4 minggu dan juga termasuk perlakuan kontrol (tanpa perendaman)

\section{Saran :}

1) Hasil penelitian ini sebaiknya diaplikasi pada kegiatan pemeliharaan benih kerang mutiara skala massal di lapangan untuk memacu pertumbuhan cangkang kerang mutiara;

2) Perlu dilakukan percobaan pada kerang mutiara dengan ukuran yang lebih besar untuk memacu pertumbuhan.

\section{SUMBER PUSTAKA}

Bachtiar, A., Sudharmawan A. A., \& Mukhlis, A. 2011. Pengaruh perbedaan komposisi pakan alami jenis Tetraselmischuii, Chlorella sp., dan Pavlova lutherii terhadap pertumbuhan dan kelangsungan hidup larva kerang mutiara Pinctada maxima. Skripsi (Tidak Dipublikasi). Program Studi Budidaya Perairan. Universitas Mataram.

Gosling, E. 2003. Bivalve Molluscs: Biology, Ecology and Culture. Fishing News Books, UK. 443 hlm.

Hadinata, F.W., Sahala, H., \& Djoko, S. 2012. Pengaruh Perbedaan Intensitas Cahaya Terhadap Pertumbuhan Dan Perkembangan Larva Kerang Mutiara (Pinctada Maxima, Jameson, 1901) Skala 
Jurnal Perikanan (2021) Volume 11. No. $1: 1-12$

DOI : https://doi.org/10.29303/jp.v11i1.224

Laboratorium. Journal of Management of Aquatic Resources. Vol. 1 (1) : 1-5

Haws, M. \& Ellis, S. 2000. Aquafarmer information sheet: Collecting blacklip pearl oyster spat. Center for Tropical and Subtropical Aquaculture Publication Number $144: 8 \mathrm{hlm}$.

Jamilah. 2015. Analisis HidroOseanografi Untuk Budidaya Tiram Mutiara di Perairan Baubau. Jurnal Biotek. Vol. 3 (2) : 92-105

Jefri, E., Yasir, I., \& Syafiuddin. 2017. Komposisi Jenis Biofouling pada Tiram Mutiara (Pinctada maxima) di Lahan Budidaya PT. Autore Pearl Culture Lombok. Spermonde. Vol. $2(3): 9-16$

Kordi, M.G.H.K. 2011. Marikultur Prinsip dan Praktik Budidaya Laut. Ed.1.-Yogyakarta: ANDI : $618 \mathrm{hlm}$

Martosudarmo, B \& Wulani, I. 1990. Petunjuk Pemeliharaan Kultur Murni dan Massal Microalga. United Nations Development Programme Food and Agriculture organization of the United Nations. Subcenter Udang Jawa Timur : 50 Hal.

Sari, I.P., \& Manan, A. 2012. Pola Pertumbuhan Nannochloropsis oculatapada Kultur Skala Laboratorium, Intermediet, dan Massal. Jurnal Ilmiah Perikanan dan Kelautan. Vol. 4 (2) : 123-127

Sujoko, A. 2010. Membenihkan Kerang 